\title{
Description of knock onset in SI turbocharged gas engine
}

\author{
Knock is an abnormal combustion process occurring in SI engines. To describe engine knock reliably is still challenge. \\ Based on measured in cylinder pressure, the techniques of knock onset determination are introduced. The findings about \\ knock intensity are discussed. Simulation of knock phenomena is mentioned. The results from model and experiment are \\ compared.
}

Key words: knock onset description, knock intensity, gas fueled engine

\section{Opis zjawiska powstawania stuku w doladowanym silniku gazowym}

\author{
Spalanie stukowe jest anormalnym procesem spalania w silniku o zapłonie iskrowym. Ciagle brakuje wiarygodnego \\ opisu zjawiska stuku. Przedstawiono sposób określania początku stuku na podstawie pomiaru ciśnienia w cylindrze. \\ Omówiono spostrzeżenia dotyczqce intensywności stuku. Wspomniano o modelowaniu zjawiska stuku. Porównano wyniki \\ modelowania z wynikami eksperymentalnymi. \\ Słowa kluczowe: opis zjawiska powstawania stuku, intensywność stuku, silnik zasilany gazem
}

\section{Introduction}

Natural gas is regarded to be a fuel with high anti-knock potential for spark-ignited engines. Therefore the knock was considered to be insignificant. But nowadays engine are designed to minimize exhaust emissions while maximizing power and fuel economy. There are certain operating conditions which lead to occurrence of a knock for these supercharged engines with high power potential [1]. Due to the potential for engine damage it is very important to avoid knock but at the same time, due to efficiency reasons, it is desirable to operate engine as close to knock combustion as possible. Therefore it is necessary to deal with anti-knock behavior of methane based fuels. There is a call for the use of experimental and model description of knock phenomena.

The objective of this paper is to introduce the techniques of knock onset determination based on experimental and simulation methods as they are used at author's workplace.

\section{Engine knock}

\subsection{Experimental knock description}

Knock is an abnormal combustion process occurring in SI engines. It results in an abnormal auto-ignition of the end gas ahead of the propagating flame front. This phenomenon is characterized by the occurrence of pressure oscillations at a characteristic frequency. It can damage pistons, rings, and exhaust valves if heavy knock occurs [2]. The detection of this abnormal combustion and the evaluation of knock intensity is therefore challenging task in engine development. Several methods have been proposed and used for knock phenomena description.

Experimental methods refer to different physical quantities which are influenced by knock occurrence. These methods can be divided into several categories according to the physical quantity they use to detect knock [3]:

\section{Wstęp}

Gaz ziemny jest uważany za paliwo charakteryzujące się dobrymi właściwościami antystukowymi w silnikach o zapłonie iskrowym. Z tego względu spalanie stukowe było uważane za nieistotne w takich silnikach. Nowoczesne silniki są konstruowane tak, aby zminimalizować wydzielanie toksycznych składników spalin a jednocześnie osiągać możliwie dużą moc przy minimalnym zużyciu paliwa. Przy pewnych parametrach pracy silnika doładowanego zachodzą warunki do wystąpienia spalania stukowego [1]. Ze względu na niszczący efekt spalania stukowego należy go unikać, a z drugiej strony ze względu na sprawność wskazana jest praca silnika jak najbliżej granicy spalania stukowego. Z tego względu konieczne jest panowanie nad tym zjawiskiem w silnikach zasilanych metanem. Do opisu zjawiska stuku używa się zarówno metod eksperymentalnych, jak i modelowania.

Celem tego artykułu jest wprowadzenie do technik opisu zjawiska powstawania stuku w oparciu o metody eksperymentalne i modelowanie jak te, które zostały przedstawione w pracy.

\section{Spalanie stukowe w silniku}

\subsection{Eksperymentalny opis stuku}

Spalanie stukowe jest zjawiskiem anormalnym zachodzącym w silniku o zapłonie iskrowym. Objawia się to anormalnym zapłonem gazu w pewnej odległości od frontu rozprzestrzeniającego się płomienia. Zjawisko to charakteryzuje się występowaniem oscylacji ciśnienia o charakterystycznej częstotliwości. Intensywnie zachodzące zjawisko stuku może spowodować uszkodzenie tłoka, pierścieni i zaworów wydechowych [2]. Wykrywanie tego anormalnego spalania i ocena jego intensywności jest zatem istotnym wyzwaniem dla rozwoju silników. Jest wiele znanych metod opisu zjawiska stuku. 
- methods based on in-cylinder pressure measurements,

- methods based on engine block vibration analysis,

- methods based on gas ionization analysis,

- methods based on heat transfer analysis.

The first method allows direct measurements of primary knock effect and detailed investigation of abnormal combustion phenomena. This category includes the largest number of methods currently used in laboratory tests. Signals generated by a pressure sensor are generally filtered in order to provide high frequency oscillations. This signal is then used to calculate knock indices. The in-cylinder pressure signal can be analyzed in the frequency domain as well. Many kinds of indices exist. Up to now, the in-cylinder pressure measurement is likely the most investigated way to detect knock because of the direct connection between knock and pressure oscillations.

The methods, currently employed on mass-produced engines for knock detection and control, are based on engine block vibration analysis. The high frequency pressure oscillations inside the cylinder, caused by end-gas autoignition, are transmitted through the engine structure, causing vibrations that can be detected by means of a vibration sensor installed on engine block. A careful selection of the most appropriate sensor location and signal processing technique is therefore required.

Alternative methods have been investigated as well. For example techniques based on gas ionization probe, by supplying a DC voltage after ignition and measuring corresponding current, in order to detect abnormal combustion phenomena through the sharp increase in ionization.

Knock detection can also be achieved through the analysis of the increase in heat transfer that accompanies the abnormal combustion. However, thermal effects are usually quite negligible under light knock conditions and hinder the successful application of these techniques for detection of knock levels, as required for knock control.

On author's workplace knock occurrence and its intensity are identified experimentally by evaluation of oscillation of in-cylinder pressure and by evaluation of vibration sensor signal using DSP based evaluation unit AKR. The first method is then primary used for off-line evaluation. Knock intensity is defined by amplitude of pressure oscillations. Knock is usually considered as occurring when the pressure oscillations exceed a predefined threshold value. Program INTEC [4] is used for evaluation in-cylinder pressure data. Figure 1 shows raw pressure trace recorded during a knocking cycle, along with the corresponding filtered signal (cut-off frequency $5 \mathrm{kHz}$ ) and difference between filtered and unfiltered pressure signal.

The second method is used for on-line monitoring of engine knock. The knock intensity is divided into three levels by the value of the output voltage from vibration sensor ECU:

$\begin{array}{ll}0 \mathrm{~V} & \text { Knock Free } \\ 0-2 \mathrm{~V} & \text { Light Knock } \\ >2 \mathrm{~V} & \text { Heavy Knock }\end{array}$

\subsection{Simulation models and knock model theory}

Simultaneously with experimental investigation effort is dedicated to use the simulation method. Simulations can be
Metody eksperymentalne odnoszą się do różnych własności fizycznych, na które ma wpływ zjawisko spalania stukowego. Metody te mogą być podzielone na kilka kategorii ze względu na własności fizyczne wykorzystane do identyfikacji stuku [3]:

- metody bazujące na pomiarze ciśnienia w cylindrze,

- metody oparte na analizie drgań bloku silnika,

- metody oparte na analizie jonizacji gazu,

- metody oparte na analizie wymiany ciepła.

Pierwsza kategoria pozwala na bezpośrednie pomiary nieprzetworzonego efektu stuku oraz szczegółowe badanie tego anormalnego zjawiska spalania. Obejmuje ona największą liczbę metod obecnie używanych w badaniach laboratoryjnych. Otrzymane sygnały z czujnika ciśnienia są zazwyczaj filtrowane w celu oddzielenia oscylacji ciśnienia o wysokiej częstotliwości. Sygnał ten jest następnie wykorzystywany do obliczania wskaźników określających spalanie stukowe. Sygnały reprezentujące ciśnienie spalania mogą być analizowane także w dziedzinie częstotliwości. Występuje wiele wskaźników opisujących spalanie stukowe. Obecnie metoda wykorzystująca pomiar ciśnienia w cylindrze jest prawdopodobnie najbardziej miarodajną drogą wykrywania spalania stukowego ze względu na bezpośredni związek stuku z oscylacjami ciśnienia.

W masowo produkowanych silnikach do wykrywania i kontroli zjawiska stuku wykorzystuje się metody oparte na analizie drgań bloku silnika. Oscylacje ciśnienia w cylindrze silnika, o wysokich częstotliwościach, spowodowane samozapłonem reszty gazu, są przenoszone przez strukturę silnika, powodują jego drgania, które mierzone są przez zainstalowane na bloku silnika czujniki drgań. Dlatego ważny jest poprawny wybór miejsca montowania czujników drgań oraz wybór techniki przetwarzania sygnałów.

Rozwijane są także metody alternatywne - na przykład techniki oparte na wykorzystaniu sond jonizacyjnych zasilanych prądem stałym. W przypadku wystąpienia anormalnego procesu spalania następuje nagły wzrost jonizacji gazu a pomiarowi podlega prąd płynący przez sondę.

Wykrywanie procesu spalania stukowego może być także osiągnięte przez analizę wzrostu wymiany ciepła, który towarzyszy takiemu spalaniu. Jednakże, w przypadku lekkiego stuku efekty cieplne są zazwyczaj niewielkie, co utrudnia zastosowanie tej metody do określania poziomu stuku.

Autorzy w pracy określali występowanie stuku oraz jego intensywność przez ocenę oscylacji ciśnienia w cylindrze oraz przez ocenę sygnału z czujnika drgań DSP z modułem AKR. Metoda pierwsza została użyta jako metoda podstawowa oceny stuku na podstawie zarejestrowanych sygnałów. Intensywność stuku jest definiowana przez amplitudę oscylacji ciśnienia. Uważa się, że zjawisko stuku występuje, gdy oscylacje ciśnienia przekraczają zdefiniowaną wartość progową. Do oceny danych zawartych w sygnale ciśnienia w cylindrze użyto programu INTEC [4]. Rysunek 1 przedstawia nieprzetworzony przebieg ciśnienia zarejestrowany podczas cyklu ze spalaniem stukowym wraz z odpowiednim sygnałem odfiltrowanym (odcięte częstotliwości $5 \mathrm{kHz}$ ) oraz różnice pomiędzy filtrowanym i niefiltrowanym sygnałem. 


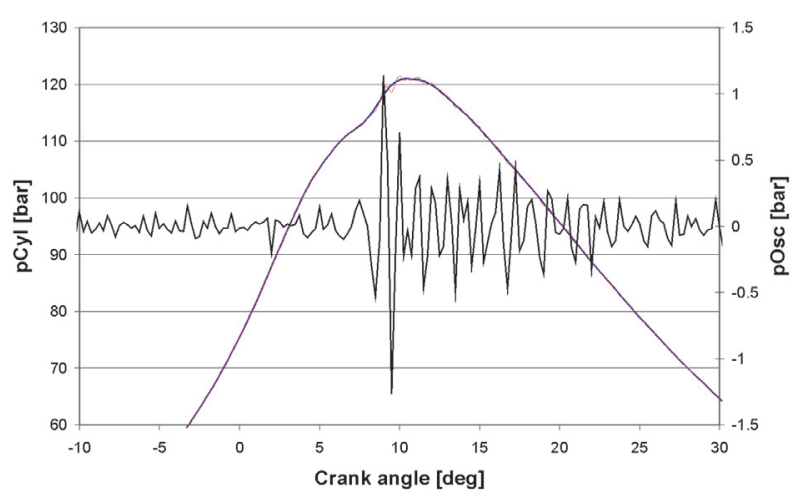

Fig. 1. Pressure oscillations on knocking engine

Rys. 1. Oscylacje ciśnienia w silniku ze spalaniem stukowym

performed with different width and depth of accuracy [2]. Knock prediction codes including detailed chemical kinetics have the largest level of physicality. These codes are based on the chemical reactions and are very complex. That is why attempts are made to implement empirical approach based on results from detailed model.

Empirical relationships are derived by matching an Arrhenius function to measured or calculated data on induction times, for given fuel-air mixtures, over the relevant mixture pressure and temperature ranges. The physicality decreases but on the other hand the computational time decrease. Introduced model is based on an empirical relationship for calculation of ignition delay. It is assumed that autoignition occurs when:

$$
\int_{\mathrm{t}=0}^{\mathrm{t}=\tau_{\mathrm{i}}} \frac{1}{\tau} \mathrm{dt}=1
$$

where $\tau$ is the induction time at the instantaneous temperature and pressure of the mixture, $t$ is the elapsed time from the start of the end-gas compression process and $\tau_{\mathrm{i}}$ is the time of autoignition.

A number of empirical relations for induction time for natural gas have been developed. These relations have the form:

$$
\tau=\mathrm{A} \cdot \mathrm{p}^{-\mathrm{n}} \cdot \exp \left(\frac{\mathrm{B}}{\mathrm{T}}\right)
$$

For following calculation the correlation included as a part of in-house code OBEH $[5,6]$ was chosen. OBEH is $0-\mathrm{D}$ model of the thermodynamics of the working cycle of the internal combustion engine, where knock model is integrated. This relation has form [7] while methane is assumed as a fuel:

$$
\tau=8.13 \cdot 10^{-4} \mathrm{p}^{-1} \exp \left(\frac{18508}{\mathrm{~T}}\right)
$$

where $\tau$ is in seconds, $\mathrm{p}$ is absolute in-cylinder pressure in $\mathrm{Pa}$, and $\mathrm{T}$ is temperature of unburned mixture in $\mathrm{K}$.

More correlations for methane and natural gas can be found in [8]. Definition of end-gas temperature is crucial when this kind of model is employed. Angle resolved patterns describing behavior of working substance during high pressure part of working cycle (in-cylinder pressure and temperature of unburned mixture) are then inputs for
Druga metoda używana jest, jako metoda on-line kontroli spalania stukowego. Intensywność stuku jest podzielona na trzy poziomy przez wartość napięcia wyjściowego z czujnika drgań ECU:

$\begin{array}{ll}0 \mathrm{~V} & \text { bez stuku } \\ 0-2 \mathrm{~V} & \text { lekki stuk } \\ >2 \mathrm{~V} & \text { silny stuk }\end{array}$

\subsection{Modele symulacyjne oraz teoria modelu stuku}

Równocześnie $z$ badaniem doświadczalnym podjęto wysiłek wykorzystania metody symulacyjnej. Symulacje mogą być przeprowadzone z różną wnikliwością i dokładnością [2]. Programy uwzględniające proces stuku zawierają szczegółowe dane dotyczące kinetyki chemicznej. Programy te bazują na reakcjach chemicznych i są przy tym bardzo złożone. Dlatego podejmowane są próby wykorzystania podejścia empirycznego bazującego na wynikach z modeli szczegółowych.

Zależności empiryczne stanowią połączenie formuły Arrheniusa z wynikami pomiaru lub danymi obliczeniowymi dla czasu inicjowania zjawiska, dla danej mieszaniny paliwowo-powietrznej i danego zakresu temperatury i ciśnienia. Jest to wprawdzie ograniczenie w opisie zjawiska, ale dzięki temu zmniejsza się czas obliczeń. Przedstawiony model bazuje na empirycznej zależności obliczanego czasu zwłoki zapłonu. Zakłada się, że samozapłon występuje, gdy (1),

gdzie $\tau$ jest czasem opóźnienia samozapłonu przy chwilowej temperaturze i ciśnieniu mieszanki palnej, t jest czasem liczonym do początku procesu sprężania reszty gazu, $\tau_{\mathrm{i}}$ jest czasem samozapłonu.

Jest wiele zależności empirycznych określających czas opóźnienia samozapłonu dla metanu. Zależności te są podawane w formie (2).

Korelacja taka została włączona do programu obliczeniowego OBEH, w którym prowadzono obliczenia. OBEH jest termodynamicznym zero-wymiarowym modelem obiegu, pracującego silnika tłokowego, z uwzględnieniem modelu stuku. Przyjmując jako paliwo metan zależność ta przybiera postać (3) [7].

$\mathrm{W}$ równaniu (3) $\tau$ wyrażone jest $\mathrm{w}$ sekundach, $\mathrm{p}$ jest ciśnieniem absolutnym w cylindrze [Pa], T jest temperaturą niespalonej mieszanki $[\mathrm{K}]$. Więcej zależności dla metanu i dla gazu ziemnego można znaleźć w pracy [8].

Dla tego rodzaju modelu kluczowe jest zdefiniowanie temperatury reszty gazu. Rozwiązanie tej zależności względem kąta, opisującej zachowanie się czynnika roboczego W wysokociśnieniowej części cyklu roboczego (ciśnienie i temperatura niespalonej mieszanki w cylindrze), stanowi dane wejściowe do obliczeń. Te dane wejściowe mogą być otrzymane $z$ analizy danych doświadczalnych przy użyciu programu INTEC lub z symulacji matematycznych z wykorzystaniem programu OBEH.

W celu określenia temperatury reszty gazu przetestowane zostały dwa podejścia (uproszczone dwustrefowe modele). OBEH bazuje na opisie bilansu energetycznego w szerokości warstwy, która nie podlega wpływowi płomienia. Jednakże wymaga to dodatkowych parametrów (fikcyjna grubość warstwy - zdefiniowana jako stosunek objętości do powierzchni i oporu cieplnego warstwy). 
calculations. These inputs can be obtained from evaluation of experimentally acquired data using INTEC or from mathematics simulations using $\mathrm{OBEH}$.

Two approaches (simplified two-zone models) have been tested to determine the pattern of end-gas temperature. $\mathrm{OBEH}$ involves a routine based on description of energy balance across the layer which is not influenced by flame. However it calls for additional parameters (fictive thickness of layer - it define volume to surface ratio and thermal resistance of layer).

The simplest method for implementation of two zone approach is based on assumption that locally averaged cylinder charge temperature represents a weighting average of temperatures of both burnt and unburned zones while the burned fraction is the weighting factor. The unburned zone temperature Tu after start of combustion is computed assuming polytropic compression of the unburned charge - two zones mean temperature model (2ZMTM). Polytropic exponent is then calculated using relationship developed by Brunt [9].

\section{Experimental results}

The experiments were simultaneously performed on two turbocharged gas fueled engines: 4xØ102/120 mm and 4xØ102/110 mm. Table 1 brings basic information about engines features. A712 engine emulates "low cost" version of nowadays engines with low boost pressure and it is used mainly for preliminary testing. G432 engine represents "state of the art" for gas engines with high boost pressure and BMEP. Figure 2 shows an example of experimental investigation. The measurements were done $1700 \mathrm{rpm}$ for widely open throttle. The Transit Natural Gas from public grid was used as a fuel. All monitored quantities were noted using DAQ system. As mentioned the intensity of knocking in measured point is described by the output voltage from vibration sensor evaluation unit (AKR in Fig. 2).

Figure 2 well demonstrates that the regimes with knocking were experimentally identified although the fuel with declared high knock resistance was used. These regimes are not so far from common working range for this type of engine.

Knock is usually described by its starting angle and by the value of normalized heat release at this onset. The value of normalized heat release is mainly used in mathematics models to describe knock occurrence and its intensity. In Fig. 3 part of output from in- cylinder pressure record evaluation is introduced for two cycles with various level of knock. This figure very well illustrates enunciation that the value of normalized heat release at knock onset doesn't determine knock intensity reliably. This value is almost same for both cases although the knock intensity identified by AKR voltage indicates significantly different level of knock. It is clear that the burning velocity is influenced when ignition timing is changed. Figure 4 then introduces patterns of in-cylinder pressures where it is possible to see difference between light and heavy knock.

Figure 5 shows patterns of filtered in-cylinder pressures for individual cycles, because the knock
Metodą prostszą do zastosowania w podejściu dwustrefowym jest bazowanie na założeniu, że lokalnie uśredniona temperatura ładunku stanowi średnią ważoną temperatur strefy spalonej i niespalonej, a część spalona jest czynnikiem ważącym. Temperatura niespalonej strefy Tu po rozpoczęciu procesu spalania jest liczona przy założeniu politropowego sprężania niespalonego ładunku - wg dwustrefowego średniotemperaturowego modelu (2ZMTM). Wykładnik politropy jest następnie liczony z wykorzystaniem zależności opracowanej przez Brunta [9].

\section{Wyniki badań eksperymentalnych}

Badania eksperymentalne były jednocześnie prowadzone na dwóch turbodoładowanych silnikach zasilanych gazem: $4 x \varnothing 102 / 120 \mathrm{~mm}$ i 4xØ102/110 $\mathrm{mm}$. Tabela 1 zawiera podstawowe informacje o badanych silnikach. Silnik A712 jest reprezentantem „niskonakładowych” współczesnych silników o małym stopniu doładowania, który jest używany głównie do badań wstępnych. Silnik G432 reprezentuje grupę współczesnych silników gazowych o dużym stopniu doładowania i dużej mocy. Rysunek 2 przedstawia przykładowe wyniki badań. Pomiary były prowadzone dla prędkości obrotowej $1700 \mathrm{obr} / \mathrm{min}$ dla pełnego otwarcia przepustnicy. Jako paliwo użyto gazu ziemnego z sieci publicznej. Wszystkie obserwowane wielkości były rejestrowane przy użyciu systemu DAQ. Jak wspomniano, intensywność stuku w punkcie pomiarowym jest reprezentowana przez napięcie wyjściowe z czujnika drgań (AKR na rys. 2).

Rysunek 2 dobrze uwidacznia zidentyfikowany eksperymentalnie obszar stuku mimo użycia paliwa charakteryzującego się zadeklarowaną odpornością na spalanie stukowe. Obszar stuku jest położony niezbyt daleko od zakresu pracy tego typu silnika.

Zjawisko stuku jest zazwyczaj scharakteryzowane przez kąt jego początku oraz przez wartość znormalizowanej funkcji wydzielania ciepła na początku jego powstawania. W modelach matematycznych do opisu zjawiska stuku oraz jego identyfikacji zazwyczaj używa się znormalizowanej funkcji wydzielania ciepła. Na rysunku 3 przedstawiono

Table 1. Experimental facilities Tabela 2. Warunki badań

\begin{tabular}{|c|c|c|}
\hline Engine/silnik & A712 & G432 \\
\hline Bore/średnica [mm] & $4 \times 102$ & $4 \times 102$ \\
\hline Stroke/skok [mm] & 110 & 120 \\
\hline $\begin{array}{l}\text { Compression ratio/sto- } \\
\text { pień sprężania }\end{array}$ & 10 & 12 \\
\hline Cylinder head/głowica & 2-valves/2-zaworowa & 4-valves/4-zaworowa \\
\hline $\begin{array}{l}\text { Turbocharger/turbodola- } \\
\text { dowanie }\end{array}$ & $\begin{array}{l}\text { Uncontrolled/ } \\
\text { niesterowane }\end{array}$ & VGT \\
\hline $\begin{array}{l}\lambda \text { - control/sterowanie } \\
\text { sondą lambda }\end{array}$ & $\begin{array}{c}\lambda=1 \text { (closed loop) or } \\
\text { lean burn } / \lambda=1 \text { (pętla } \\
\text { zamknięta) lub mieszanki } \\
\text { ubogie }\end{array}$ & $\begin{array}{c}\lambda=1 \text { (closed loop) or } \\
\text { lean burn } / \lambda=1 \text { (pętla } \\
\text { zamknięta) lub mieszanki } \\
\text { ubogie }\end{array}$ \\
\hline EGR & No/brak & $\begin{array}{l}\text { Cooled up to } 20 \% / \\
\text { chtodzony do } 20 \%\end{array}$ \\
\hline $\begin{array}{l}\text { Intercooler/chtodnica po- } \\
\text { wietrza doładowujacego }\end{array}$ & Not at all/wybrane & Powerfull \\
\hline
\end{tabular}



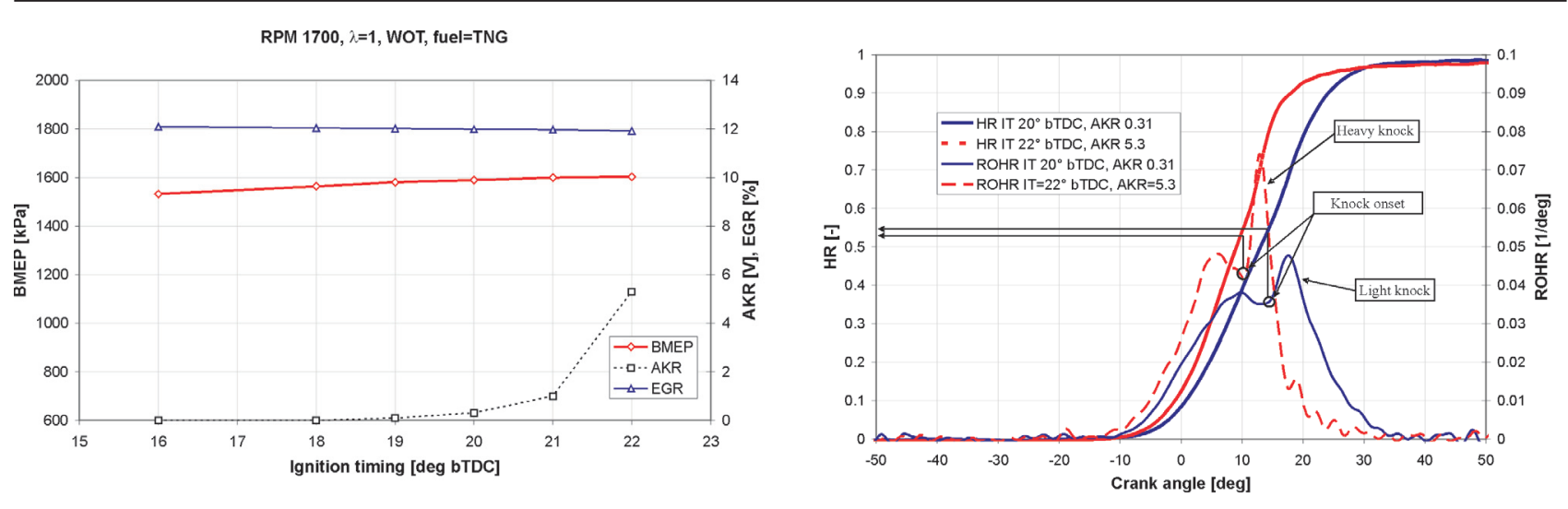

Fig. 3. Knock onset description

Rys. 3. Opis początku stuku

Rys. 2. Przykład wyników badań eksperymentalnych na silniku G432

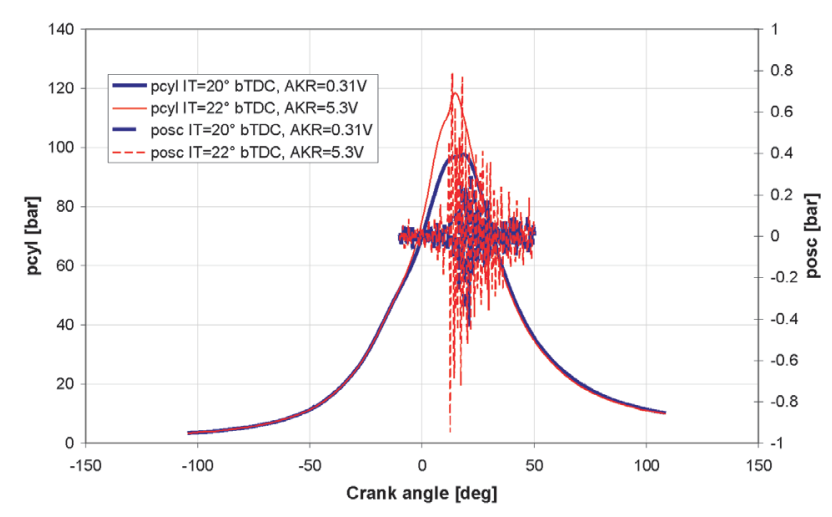

Fig. 4. In-cylinder pressure for knocking cycles Rys. 4. Ciśnienie w cylindrze ze stukiem

onset is well visible only from actual cycle. It represents differences between the actual cycles - well known as a cycle to cycle variability. Moreover there is variation enhanced by cycles with a without knocking in this case. The percent occurrence of knocking cycles should be used as knock intensity indicia. Figure 6 introduces measured knock onsets for above mentioned two operating points with different level of knock intensity. Value 50 of knock onset represents cycle where the knock didn't occur. Knock onsets are evaluated using INTEC. All individual cycles must be browsed in order to write down all knock onsets correctly. The application for evaluation of knock onset position is under preparation using Lab-View software. It is visible that when light knock takes place the record contains approx. $22 \%$ of knocking cycles. The number of knocking cycles is approx. 54\% in case of heavy knock. The averaged value of knock onset is determined from this record. The averaged value can be compared with knock onset from simulation.

\section{Model results}

Inputs for knock model (in-cylinder pressure and temperature of unburned mixture) can be obtained directly from experiments (two zone model is used) and from code OBEH or from any other commercial code (0-D, 1-D). Former strategy in modeling of knocking is described in [10]. The main effort is dedicated to obtain very similar values of knock onsets for every operating point.

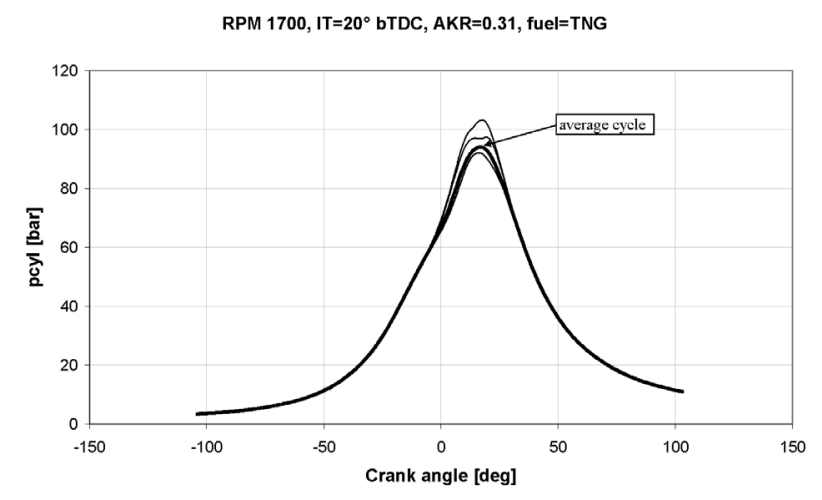

Fig. 5. Cycle to cycle variation

Rys. 5. Niepwotarzalność cykli

zarejestrowane wyniki pomiaru ciśnienia dla dwóch cykli o różnym poziomie stuku. Bardzo dobrze uwidaczniają one, że wartość znormalizowanej funkcji wydzielania ciepła na początku stuku nie daje pełnej informacji o intensywności stuku. Wartość ta jest prawie taka sama dla obydwu przypadków, mimo że określony poziom intensywności stuku na podstawie sygnału napięciowego z AKR jest inny. Wyraźnie widać, że szybkość spalania zmienia się przy zmianie czasu wystąpienia zapłonu. Rysunek 4 przedstawia przykłady przebiegu zmian ciśnienia $\mathrm{w}$ cylindrze $\mathrm{z}$ uwidocznioną różnicą między lekkim a mocnym stukiem.

Rysunek 5 przedstawia przykład odfiltrowanego przebiegu ciśnienia dla pojedynczych cykli, ponieważ początek stuku jest dobrze widoczny tylko dla bieżącego cyklu. Widać tutaj różnice pomiędzy cyklami, co jest dobrze znane, jako niepowtarzalność kolejnych cykli. Dodatkowo zjawisko to jest potęgowane przez obecność cykli z i bez zjawiska stuku. Procentowy udział cykli ze stukiem używany jest jako wskaźnik intensywności stuku.

Rysunek 6 przedstawia początki stuku dla wyżej wymienionych dwóch punktów pracy o różnym poziomie intensywności stuku. Wartość 50 przy określaniu stuku oznacza cykle, w których zjawisko stuku nie zaistniało. Do wyznaczenia początku stuku użyto programu INTEC. W celu otrzymania prawidłowych wartości początku stuku analizie poddawane były pojedyncze cykle. Program do analizy położenia początku stuku został napisany w środowisku Lab-View. Można zauważyć, że gdy występuje lekki 


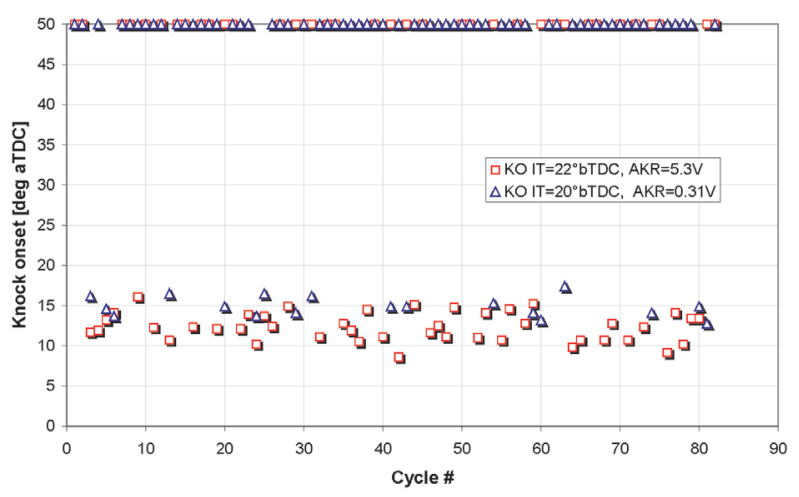

Fig. 6. Knock onset position

Rys. 6. Położenie poczatku stuku

Preliminary results do not show good agreement with experimentally determined knock onsets. It was find out those differences between model and experimental data are given mainly by interpretation of evaluated knock onsets from experiment. In case when the value of the mean knock onset for given operating point is compared with results from model where the averaged input data were used the results are not promising. Figure 7 just describes variability of in-cylinder pressure traces for different way of evaluating. It is well visible that for operating point where the light knocks were measured the averaged pattern for ROHR doesn't contain information about knocking. Simultaneously the maximum of the incylinder pressure is lower in comparison with the maximum which corresponds to averaged pressure trace evaluated when only knocking cycles were taken into the account. It is clear that data generated by averaging of only the knocking cycles are more suitable as the inputs for the knock model when the results from model are consequently compared with averaged value of knock onset evaluated from experiment.

Figure 8 shows comparison between results from knock model and averaged knock onsets evaluated from experiments. The number 50 on knock onset axis represents knock free cycle. For model inputs based only on averaged values results from experiments do not show good agreement nevertheless the demand on plausible description of engine operating points with and without occurrence of knock is realized. These results demonstrate well above mentioned statement

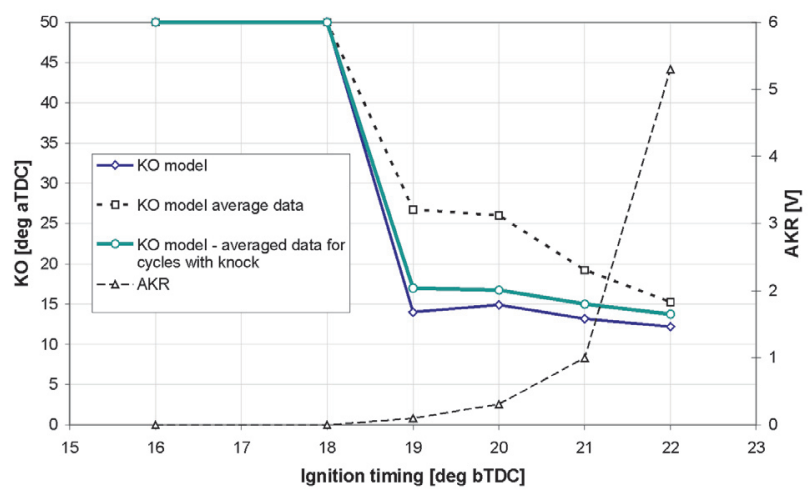

Fig. 8. Knock model results Rys. 8. Wyniki modelowania stuku

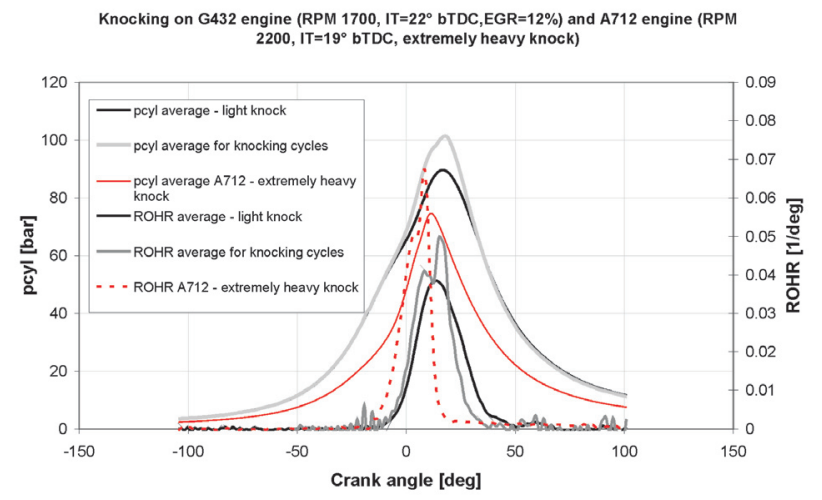

Fig. 7. Different in-cylinder pressure traces used as the input for simulation Rys. 7. Różnice w przebiegach ciśnienia użytych jako dane wejściowe do modelowania

stuk w zbiorze zawartych jest około $22 \%$ cykli ze stukiem. W przypadku występowania silnego stuku liczba cykli ze stukiem wynosiła około $54 \%$. Na podstawie tych danych została określona wartość średnia początku stuku. Ta wartość średnia może być porównywana $\mathrm{z}$ wynikami modelowania.

\section{Wyniki modelowania}

Dane wejściowe do modelu stuku (ciśnienie i temperatura niespalonej mieszanki w cylindrze) mogą być zaczerpnięte z badań eksperymentalnych (użyto modelu dwustrefowego) oraz z programu OBEH lub z innego programu komercyjnego. Podstawowe założenia modelowania stuku zawarte są w [10]. Główny nacisk położono na uzyskanie zbliżonych wartości początku powstawania stuku dla wszystkich punktów pracy.

Wstępne wyniki modelowania nie wykazały dużej zgodności w określaniu początku powstawania stuku z wynikami eksperymentalnymi. Odkryto, że różnice te pomiędzy modelem a eksperymentem wynikają głównie z interpretacji oszacowania początku stuku na podstawie eksperymentu. W przypadku, kiedy średnia wartość początku stuku dla danego punktu pracy zostanie porównana $\mathrm{z}$ wartością uzyskaną $\mathrm{z}$ modelowania, w którym jako dane wejściowe użyto wartości średnich, to rezultaty nie są satysfakcjonujące. Rysunek 7 przedstawia różnice $\mathrm{w}$ uzyskanych przebiegach ciśnienia $\mathrm{w}$ cylindrze przy różnych sposobach oszacowania. Wyraźnie widać, że dla punktu pracy, gdzie zmierzono lekki stuk, uśredniony przebieg dla ROHR nie zawiera informacji o stuku. Jednocześnie maksymalne ciśnienie w cylindrze jest niższe w porównaniu z ciśnieniem odpowiadającym uśrednionemu ciśnieniu uzyskanemu w warunkach występowania we wszystkich cyklach zjawiska stuku. Oczywiste jest, że dane uzyskane w wyniku uśredniania tylko cykli ze stukiem są odpowiedniejszymi danymi wejściowymi do modelu stuku, i wtedy wyniki modelowania są porównywane z wartością początku stuku otrzymaną eksperymentalnie.

Na rysunku 8 przedstawiono porównanie wyników modelowania stuku z wynikami rzeczywistymi uzyskanymi przez uśrednianie cykli ze stukiem. Wartość 50 na osi początku stuku oznacza cykle bez stuku. Dla modelu, w którym dane wejściowe bazowały tylko na wartościach uśrednionych, wyniki nie dawały zadowalającej zgodności z eksperymentem. Mimo tych różnic, dla potrzeb opracowania, zrealizowano 
that the input data for knock model must be generated only from knocking cycles because the difference between results from model and from experiment is less for regimes with higher knock intensity. The results from knock model using averaged data for cycles with knock are introduced in Fig. 8 as well. The results looks very promising nevertheless the purposed strategy must be verified.

The in-house multi-zone model is modified in order to obtain more accurately information about behavior of working substance during high pressure part of working cycle. Accurately description of behavior of working substance could bring some new findings. Knock model should be further modified upon these findings.

\section{Conclusion}

The experimental and simulation methods implemented for knock phenomena description at author's workplace were introduced. Regimes with occurrence of knock were experimentally identified. The statement that the value of normalized heat release at knock onset doesn't determine knock intensity reliably was demonstrated. The examples of results from experiments and simulations were introduced. The new strategy for input data preparation was introduced.

\section{Acknowledgement}

The results presented in the article have been obtained in the framework of participation of author's workplace in the Integrated project InGas Integrated Gas Powertrain - Low Emission, $\mathrm{CO}_{2}$ optimized and efficient CNG engines for passengers cars (PC) and light duty vehicles (LDV) SCS7-GA-2008-218447.

\section{Paper reviewed/Artykut recenzowany}

\section{Bibliography/Literatura}

[1] Takáts M.: Odolnost plynných paliv proti klepání. XXXVI konference kateder a pracovišt' spalovacích motorů, českých a slovenských vysokých škol, 2006.

[2] Heywood J. B.: Internal Combustion Engine Fundamentals. McGraw-Hill, Inc., 1988.

[3] Millo F., Ferrari, C.V.: Knock in S.I. Engines: A Comparison between Different Techniques for detection and Control (1998), San Francisco, 1998, SAE 982477.

[4] Takáts M.: INTEC programové vybavení pro termodynamickou analýzu indikátorových diagramů. Knihovna programů Výzkumného Centra Josefa Božka, ČVUT Praha, 2000.

[5] Macek J.: Matematický model pracovního oběhu pístového spalovacího motoru. Knihovna programů Ú220, OBEH.EXE.

[6] Vávra J.: Preprocesor RUNOBEH.XLS, [Výzkumná zpráva], Praha, ČVUT FS, Ústav automobilů, spalovacích motorů a kolejových vozidel, 2001.

Mr. Vojtěch Klír, Eng. - Assistant, Faculty of Mechanical Engineering, Czech Technical University in Prague.

Inż. Vojtěch Klír - Asystent na Wydziale Mechanicznym Politechniki w Pradze.

e-mail:vojtech.klir@fs.cvut.cz

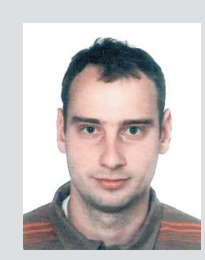

je dla różnych punktów pracy silnika z i bez zjawiska stuku. Na podstawie przedstawionych wyników można sformułować wniosek, że dane wejściowe do modelu stuku powinny pochodzić tylko z cykli ze spalaniem stukowym, ponieważ różnica pomiędzy wynikami z modelowania a wynikami z eksperymentu jest mniejsza dla warunków pracy silnika $\mathrm{z}$ wysokim poziomem stuku. Wyniki modelowania, w którym przyjęto uśrednione dane z cykli ze stukiem są przedstawione także na rys. 8. Wyniki wyglądają bardzo obiecująco, chociaż sposób postępowania musi być zweryfikowany.

Wykorzystany wielostrefowy model jest ciągle modyfikowany pod względem uzyskiwania bardziej dokładnych informacji o zjawisku zachodzącym w ładunku w wysokociśnieniowej części cyklu roboczego silnika. Dokładny opis zjawiska zachowania się czynnika roboczego może przynieść nowe informacje. Model spalania powinien być wtedy poszerzony o te informacje.

\section{Wnioski}

Przedstawiono pracę autorów dotyczącą użycia metod eksperymentalnych i symulacyjnych do opisu zjawiska spalania stukowego. Warunki pracy silnika z występującym stukiem zostały wyznaczone eksperymentalnie. Stwierdzono, że wartość znormalizowanej funkcji wydzielania ciepła dla określenia parametrów stuku nie sprawdza się. Przedstawiono przykłady wyników eksperymentalnych i wyników modelowania. Zaprezentowano nowy sposób przygotowywania danych wejściowych do modelu.

\section{Podziękowanie}

Wyniki przedstawione w artykule uzyskane zostały w ramach projektu: InGas Integrated Gas Powertrain - Low Emission, $\mathrm{CO} 2$ optimized and efficient $\mathrm{CNG}$ engines for passengers cars (PC) and light duty vehicles (LDV) SCS7GA-2008-218447.

[7] Polášek M., Hofman K.: Simulation of knock invocation in cylinder of SI engine. Konference kateder a pracovišt' spalovacích motorů, 2002.

[8] Samuelsen S., McDonell V.: Correlation of Ignition Delay with Fuel Composition and State for Application to Gas Turbine Combustion, University of California, 2003.

[9] Brunt M.F.J., Emtage A.L.: The Calculation of Heat Release Energy from Engine Cylinder Pressure Data, Detroit, 1998, SAE 981052.

[10] Klír V.: Experimental and Model Description of Engine Knock in a Turbocharged SI engine In: MECCA Journal of Middle European Construction and Design of Cars. 2009, vol. 6, no. 2, p. 23-27. ISSN 1214-0821.

Prof. Michal Takáts, DSc., DEng. - professor at Faculty of Mechanical Engineering, Technical University in Prague.

Prof. dr hab. inż. Michal Takáts - profesor na Wydziale Mechanicznym Politechniki w Pradze. e-mail:michal.takats@fs.cvut.cz 